\title{
Construction defects define pattern and method in comb building by honeybees
}

\author{
HR Hepburn *, LA Whiffler \\ Department of Zoology and Entomology, Rhodes University, Grahamstown 6140, South Africa
}

(Received 29 January 1991; accepted 25 April 1991)

\begin{abstract}
Summary - In comb building several festoons may begin building at independent sites. Combs are made parallel by manipulating the length of the cells but dislocated combs are incorporated into the total nest structure. Parallelism is achieved through passive application of the bee space. Cell size and orientation vary independently and are unique to each festoon and comb. Combs are joined laterally near their mid-sections and are usually out of register. Cells are approximately hexagonal within a comb, but poor fit requires the insertion of pentagons, heptagons, and the use of fill and vacancies for the fusion of small combs into a single large comb. Poor fit of adjacent combs occurred in $\approx$ $96 \%$ of all cases examined in A m capensis.
\end{abstract}

comb building / defects / Apis mellifera capensis

\section{INTRODUCTION}

The combs of honeybees are time-frozen records of what transpired within festoons where building is done. Analyses of these constructions have established that the basic shape of the cell is only approximate (Vogt, 1911) and that possible configurations of cells are precisely limited (Thompson, 1930). Irregularities in combs have also been documented (Vogt, 1911; Hubbe, 1957) as have comb repair and finishing (Darchen, 1968). This in turn has led to studies of the relevant sensory physiology (Martin and Lindauer, 1966) and building tolerances (Hepburn, 1983) of honeybees. Collectively this data sug- gests that many steps in construction are independent of one another and are not necessarily constrained by what has gone before (Hepburn, 1986). We now report that alignment faults within and between combs are rich sources of information as to building "rules" used by honeybees.

\section{MATERIALS AND METHODS}

Observations were made on combs built by 24 colonies of Apis mellifera capensis and 9 colonies of $A m$ scutellata in frames without beeswax foundation. Average colony size was $\approx$ 8000 bees kept in nucleus boxes with 3 frames of brood and stores and 2 empty building frames. Frames were harvested weekly and

\footnotetext{
* Correspondence and reprints
} 
105 samples of the early stages of comb building were obtained. Comb building starting sites and measurements of comb spacings were made from 9 capensis colonies kept in completely frameless hives. Combs were harvested a month or so after feral swarms had begun to construct combs. The combs depicted in figures 4,6 and 7 were made by xeroxing the original combs, and then enlarging the Xerox copy with an Eskosot process camera which gives a true image. The Eskosot copy was placed on a light table and the final images were traced directly by hand.

\section{RESULTS}

A frameless hive only constrains comb building in the axis of the substrate to which the combs are attached. In this case the Cape honeybee builds sets of combs that are nearly parallel (fig 1). However,

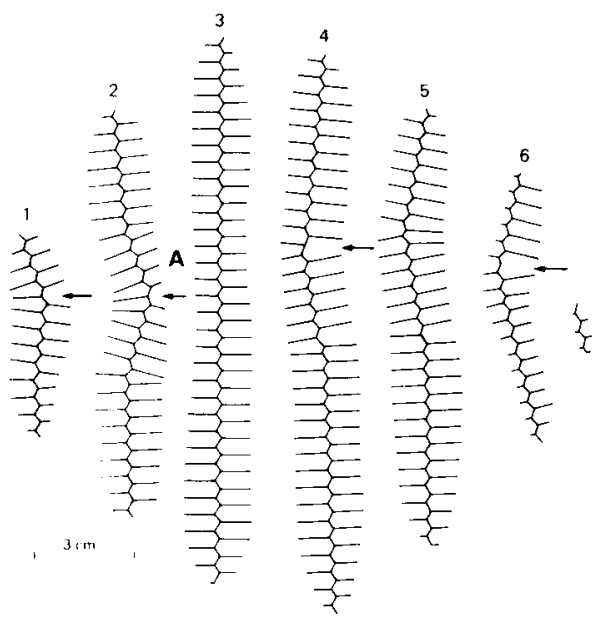

Fig 1. Cross-section of comb near its base of attachment to roof of frameless hive built by Cape honeybees. Combs that are almost parallel are achieved at the expense of cell length (region $A$ between combs 2 and 3 ) and the introduction of irregularities of the cell base in most combs (arrows). Combs 4,5 and 6 show the same effects but in the opposite direction. they often begin building simultaneously at different sites and with different results. For example, a central comb may be flanked by others whose mid-wall axes deviate substantially from the middle comb (fig 2). These 3 combs would have merged with additional lateral growth except for the rules of parallelism and the bee space. Other anomalies are depicted in figure 1 where combs 1, 2 and 3 curve but remain parallel. At region $A$ parallelism results from adjustments to cell length whilst maintaining the bee space. The mirror image situation is shown by combs 4,5 and 6 (fig 1). In another case, 4 starting sites led to a spatial difficulty that was resolved by constructing a vertical tongue of comb not connected to its neighbours (comb 4, fig 3).

In the absence of frames new comb starting sites are set apart at distances which ultimately reflect midwall spacings for a race of honeybees. For the Cape honeybee this is $\approx 27.9 \pm 3.3 \mathrm{~mm}$ (figs 1 3 ). In a frame, the starting points for combs (centre of basal attachment) are in the same vertical plane as the tip of the growing comb (fig 4). Taking the midpoints of the comb bases as reference points, the distance between any 2 adjacent combs of capensis ranged from 59-158 $\mathrm{mm}$ (mean $=86.8 \pm 21.6 \mathrm{~mm})$. In nearly all cases $(n=$ 107) the growing comb is tongue-shaped with a waist-like construction at the base (fig 5). In the early stages of growth the ratio of vertical to horizontal increase is $\approx$ $1.4: 1$ (fig 5), but becomes nearly $1: 1$ by the time adjacent combs are joined (figs 4,5 ).

Only 2 configurations of hexagons, vertical and tilted, were observed in combs of the Cape honeybee. Nonetheless, the independence of building by 2 adjacent festoons is shown by the degree of misalignment between 2 neighbouring combs. Only 3 of 89 pairs were both completely vertical in orientation and with cells that were in register. The frequency distribution of the 


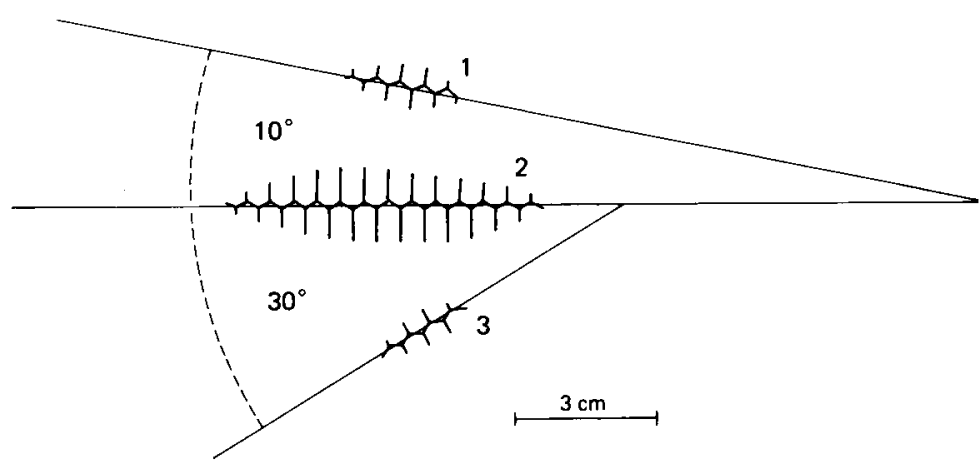

Fig 2. Cross-section of naturally built comb of the Cape honeybee illustrating that 3 independent comb starting sites have resulted in a misalignment of the 2 outer combs ( 1 and 3 ) with respect to middle comb (2). Induction of parallelism between combs is achieved only at a later stage of building (cf fig 3).

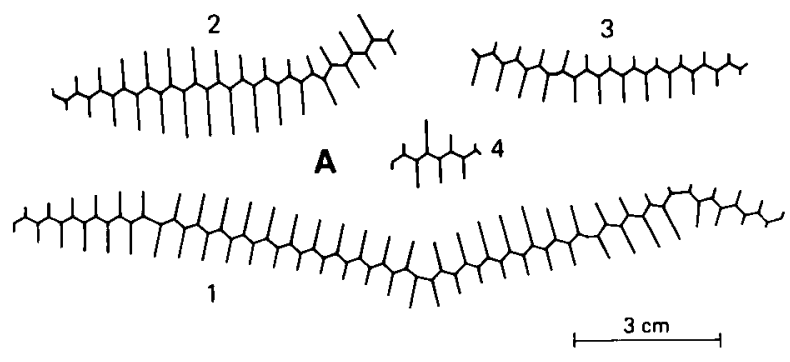

Fig 3. Cross-section of naturally built comb of the Cape honeybee near its base illustrating problems of parallelism arising from at least 4 separate starting sites (1-4). The bee space rule is used to achieve parallelism between combs 1 and 2 and 3 at their outer ends. The occurrence of a comb insertion (4) causes a dislocation of pattern and a shifted referential frame for alignment of combs 1,2 and 3 to the small insertion comb, 4 .

angles of departure between the orientation of 2 combs in a pair based on an interval of $10^{\circ}$ is as follows: $1-10^{\circ}, n=58$; $11-$ $20^{\circ}, n=21 ; 21-30^{\circ}, n=3 ; 31-40^{\circ}, n=3$. Only 20 combs were vertical to the base, but 17 of these had cell orientations pitched at angles that did not correspond with the orientation of the other comb in the pair. In addition, 7 of 89 comb pairs actually tilted in opposite directions.
Geometrical congruence between combs is thus rare and packing defects at points of fusion between combs occurred in $96 \%$ of all cases. The observed defects included: 1) changes in cell size and shape (figs 4,6 and 7 ); 2) the use of pentagonal and heptagonal cells (figs $6 \mathrm{~A}, 7$ ); 3) irregular "cells" or vacancies between cells (figs $6 \mathrm{~B}, 7$ ) and the use of solid fill (fig $6 \mathrm{~B}$ ). The relative occurrence of these defects in the 


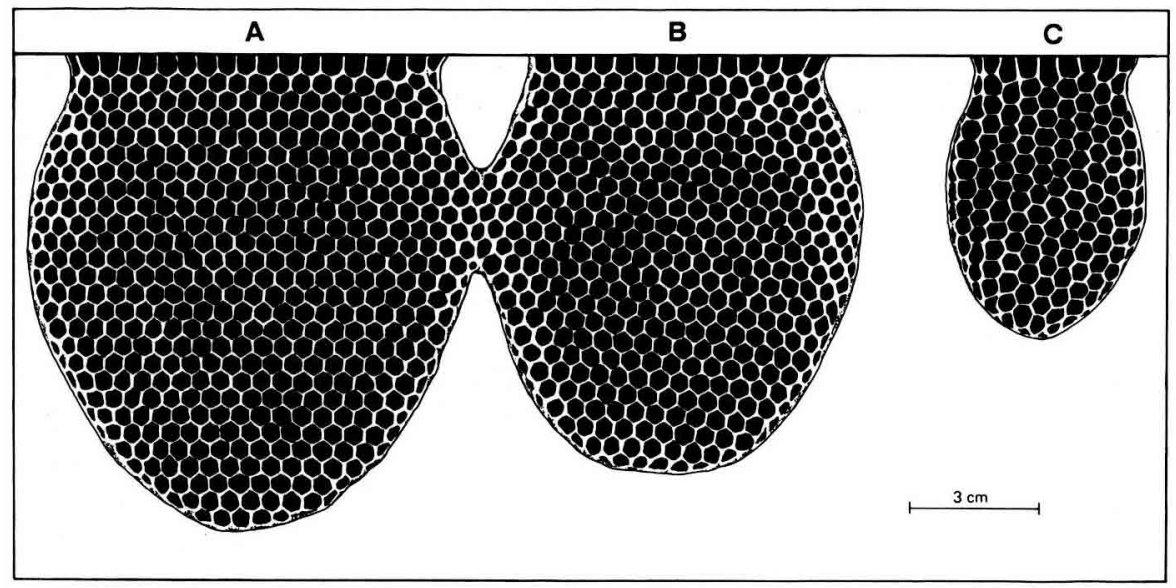

Fig 4. Comb built by the Cape honeybee within a normal hive frame. Individual tongues of comb begin at separate sites (A, B and C) and construction proceeds independently in each festoon until they merge laterally.

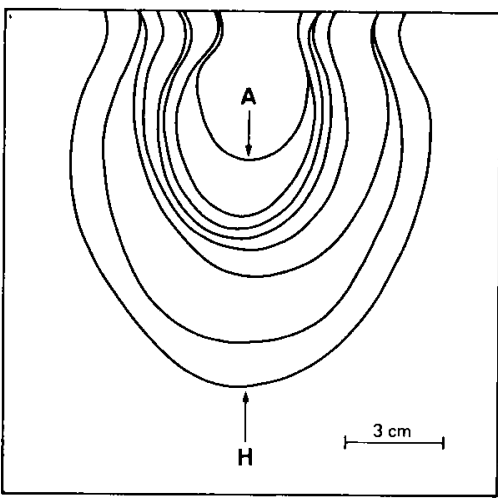

Fig 5. Diagrammatic composite form of comb tongue growth showing characteristic waist-like attachment to frame base, based on 107 individual comb starts. The ratio of vertical to horizontal increase is $1.4: 1$ at-stage $A$, but gradually changes to $1: 1$ by stage $H$ when the comb is usually fused to an adjacent one of about the same size (cf fig 4).
Table I. Pattern defects in the seams joining adjacent combs in $A m$ capensis and $A m$ scutellata*.

Character $\quad \begin{gathered}A m \\ \text { capensis }\end{gathered} \underset{\text { scutellata }}{A \text { m }}$

Comb seams, $n$

$43 \quad 21$

Seams with faults

30

18

Solutions to faults:

Cell size changes

Pentagons

$\begin{array}{rl}8 & 0 \\ 7 & 5 \\ 3 & 0 \\ 23 & 8 \\ 2 & 3 \\ 8 & 3\end{array}$

* The sums of solution of faults exceed the numbers of seams with faults for both races because more than one solution is contained in a seam. 


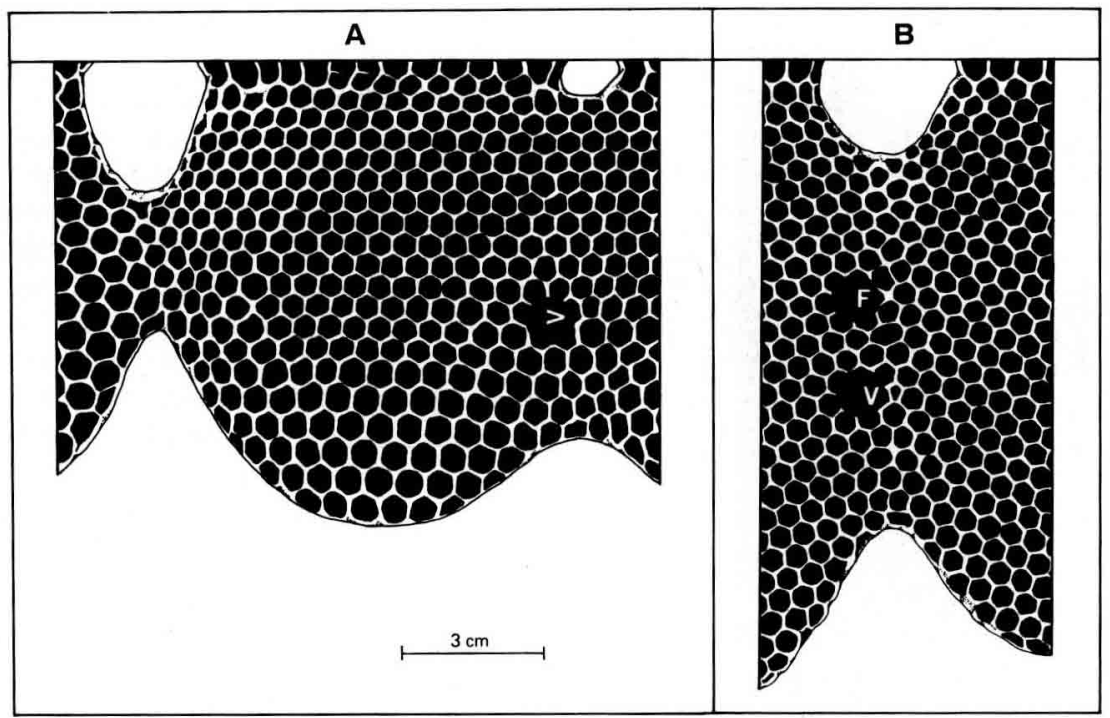

Fig 6. Pattern defects in the seams of naturally-built comb of the Cape honeybee. Changes in cell size and shape and the insertion of a pentagon and heptagon back-to-back forming a dislocation (arrow) in cell row register. B. Vacancies (V), fills (F) and pentagons and heptagons.

combs of capensis and scutellata is indicated in table I. Defects of comb fusion also occur at the bases of combs in the form of open arcs or circular holes (fig 7) which remained unfilled in finished combs.

\section{DISCUSSION AND CONCLUSION}

The occurrence of parallelism between combs, even curved ones, is recognised as a building rule (Darchen, 1954, 1968). The present data show how and when the rule is applied. When several comb starting sites are developed simultaneously, the midwalls of adjacent combs are not parallel (figs 1-3). Parallelism is affected in the finishing stages of construction and is achieved only indirectly through maintenance of a bee space. This explains how the extraordinary irregularities in cell walls and bases can be accommodated (figs 13). An alignment defect among comb bases (eg comb 4, fig 3) is also a packing dislocation which is acceptable to the bees and which eventually takes shape under the rule of parallelism. Incorporation of all of the defects discussed thus far can be explained through a passive application of the bee space.

In the lateral fusion of combs the major problem is cell register along the seam. Lack of register arises through variations in the distance between starting points for different combs and from variations in cell sizes and orientation patterns (Vogt, 1911; Hepburn, 1983, 1986). These problems are overcome in different ways (table I) but the pentagon is the primary solution. Whether a seam is made with just penta- 


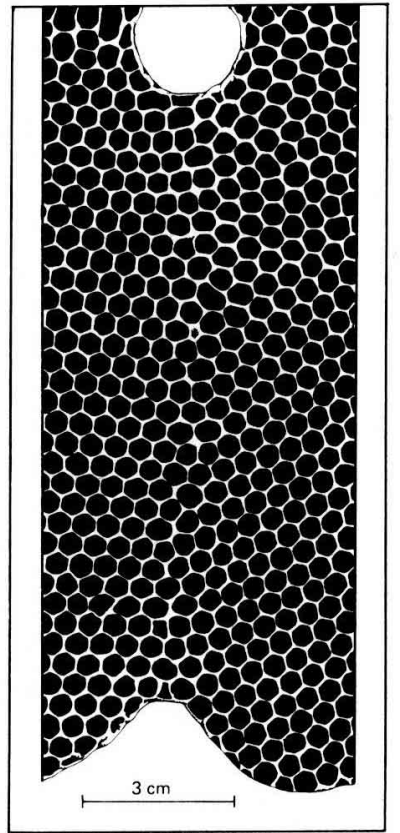

Fig 7. Propagation of dislocation in a seam between 2 fused combs terminating in an unfillable arc at the base of the 2 combs.

gons or with a pentagon and heptagon appears to be related to the size of the gap (resulting from the natural curvature of the sides of combs) between 2 combs to be joined. If this linear distance exceeds the longest line which workers will construct (eg width of a cell wall) then heptagons are used. That a bisected heptagon gives 2 pentagons may explain the occurrence of clustered pentagons.

Lack of register between combs thus leads to the introduction of dislocations (figs 6,7 ) which, while they are propagated, more or less allow for comb realignment except at the comb base. Towards the bases of the combs are unfilled holes, associated with a proliferation of disloca- tions, that cannot be filled with any regular polyhedra of cell size dimensions. The retouching of cells after construction (Darchen, 1968) does not eliminate dislocations. It merely enlarges or reduces them. Of the greatest interest here is that regular comb pattern of hexagons is consistently built among separate combs and that heptagons or pentagons are employed without reference to the cell base. The cell base may consist of from 1-7 seven different surfaces, regularity among them being rare (Hubbe, 1957). Nonetheless, regular cells are constructed upon irregular bases making these 2 operations entirely separate (Hepburn, 1983).

To summarize, simultaneous and different comb starts in unconstrained nest cavities lead to misalignments between combs. The constructions are developed whether symmetrical or not. Parallelism between combs, even curved ones, is determined by the bee space which overrides all defects in cell bases and in the lengths and angles of cell walls. The lateral fusion of combs almost always leads to packing faults that can only be resolved with nonhexagonal polyhedra. The collective defects within and between combs indicate that the metrological abilities of bees are rather limited. What we have traditionally interpreted as building "rules" (parallelism, midwall-to-midwall spacings and the bee space (cf Hepburn, 1986) can be parsimoniously explained as by-products of sensory physiology, only requiring the proprioception of worker bees coming closer together, back-to-back, and little metrological ability beyond estimating the length of a straight line segment.

Résumé - Les défauts de construction définissent le plan et la méthode de construction des rayons par l'abeille. La construction des rayons par Apis mellifera 
capensis a été observée dans des ruches avec et sans cadres. Dans les ruches sans cadres, plusieurs points de départ non coordonnés sont utilisés. Cela provoque des défauts dans l'alignement, dus à la courbure des rayons (fig 1), à la déviation des axes des parois médianes (fig 2) et à des désorganisations dans le plan de construc. tion du rayon (fig 3 ). Tous ces défauts ne sont pas corrigés mais incorporés dans la structure finale du nid par le parallélisme. Lorsque les abeilles construisent dans des cadres, différents types de défauts surviennent quand les rayons sont réunis latéralement pour former un seul grand rayon. Les défauts sont provoqués par des variations dans la distance entre les points de départ (59-158 mm, fig 4), par des changements dans les taux de croissance verticale et horizontale des rayons (fig 5) et par des variations dans la taille des cellules, leur forme et leur orientation (fig 4, 6 et 7). Tous ces défauts donnent des rayons qui, à leur point de jonction latérale, ne sont pas dans l'alignement les uns des autres. Dans $95 \%$ des cas examinés, il y avait une non-conformité entre 2 rayons de ce type. Les défauts associés à la réunion des rayons ne sont pas corrigés, mais compensés par l'introduction de cellules pentagonales et hexagonales (fig $6 \mathrm{~A}$ et 7 ), de cellules irrégulières ou de trous entre les cellules (fig $6 \mathrm{~B}$ et 7 ), et par le remplissage à l'aide de cire solide (fig 6B). Les cellules pentagonales sont les plus utilisées (tableau 1). Les nids terminés renferment des rayons avec des défauts à leurs points d'attachement, dans la base des cellules et dans la longueur des parois des cellules (fig 1-3), défauts qui sont surmontés en rendant les rayons parallèles. Un mauvais ajustement entre les rayons qui doivent être fusionnés latéralement provoque toujours la propagation de la désorganisation. On en déduit que construire un nid homogène et fonctionnel à partir de rayons comportant des défauts ne nécessite que l'ap- plication passive de l'espacement entre rayons, et peut-être aussi la capacité de mesurer la longueur d'un segment de droite.

\section{construction / rayon / défaut / Apis mel- lifera capensis}

\section{Zusammenfassung - Konstruktionsde- fekte bestimmen Muster und Methode des Wabenbaues bei der Honigbiene.} Bei Völkern von $A m$ capensis mit und ohne Rähmchen wurden Beobachtungen über den Wabenbau angestellt. Bei rähmchenlosen Stöcken wird der Bau an mehreren, unkoordinierten Ansatzstellen begonnen. Das hat Fehler der Ausrichtung wegen Krümmung der Waben (Abb 1), Abweichungen der Mittelrippe (Abb 2) oder Verschiebungen im Wabenmuster (Abb 3) zur Folge. Alle diese Fehler blieben unkorrigiert, und sie wurden in die endgültige Neststruktur unter paralleler Ausrichtung eingebaut. Verschiedene Arten von Fehlern entstehen, wenn Bienen in Rähmchen bauen und mehrere Wabenansätze seitlich miteinander verschmelzen, um eine einzige große Wabe zu bilden. Die Fehler werden durch Unterschiede in den Abständen der Anfangsstellen (zwischen 59-158 $\mathrm{mm}$, siehe auch Abb 4), Veränderungen im Verhältnis des vertikalen und horizontalen Wachsens der Waben (Abb 5) und Schwankungen von Größe, Form und Orientierung der Zellen verursacht (Abb 4, 6 und 7). Alle diese Fehler führen zu Waben, deren Muster an der Linie der seitlichen Verschmelzung nicht miteinander übereinstimmen. In $96 \%$ der untersuchten Fälle paßten die Muster dieser Waben nicht zusammen. Defekte, die bei der Verschmelzung von Waben entstehen, werden nicht korrigiert. Sie werden durch Einsetzen von fünf- und siebeneckigen Zellen (Abb 6A und 7), durch unregelmäßige Zellen, durch Leerstellen zwischen 
Zellen ( $\mathrm{Abb}$ 6B und 7) oder durch Ausfüllen mit solidem Wachs (Abb 6B) angepaßt. Fünfeckige Zellen werden am häufigsten benutzt (Tabelle I). Fertig ausgebaute Nester enthalten Waben mit Fehlern an den Anheftungsstellen, am Zellboden und in der Länge der Zellwände (Abb 1-3). Diese Fehler werden durch parallele Ausrichtung der Waben ausgeglichen. Ein schlechtes Zusammenpassen der seitlich zu verschmelzenden Waben kann nicht aufgehoben werden, sondern es wird immer weitergeführt. Es wird der Schluß gezogen, daß zum Einbau von fehlerbeladenen Waben in ein einheitliches und funktionsgerechtes Nest nichts weiter erforderlich ist als die passive Anwendung des Wabenabstandes ("bee space") und möglicherweise auch dje Fähigkeit zur Messung der Länge einer bestimmten Strecke.

Wabenbau / Defekte / Apis mellifera capensis

\section{REFERENCES}

Darchen R (1954) Quelques régulations sociales dans les constructions chez les abeilles. Insectes Soc 1, 219-228

Darchen R (1968) Le travail de la cire et la construction dans la ruche. In: Traité de Biologie de l'Abeille (Chauvin R, ed) Masson, Paris

Hepburn HR (1983) Comb construction by the African honeybee, Apis mellifera adansonii. $J$ Entomol Soc Afr 46, 87-101

Hepburn HR (1986) Honeybees and Wax. Springer, Berlin

Hubbe W (1957) Beobachtungen zum Wabenbau der Honigbiene Apis mellifera L. Arch Geflügel Kleintier Kd 6, 343-358

Martin H, Lindauer M (1966) Sinnesphysiologische Leistungen beim Wabenbau der Honigbiene. Z Vgl Physiol 53, 372-404

Thompson $F(1930)$ Observations on the positions of hexagons in natural comb building. Bee World 11, 107

Vogt H (1911) Geometrie und Ökonomie der Bienenzelle. Trewend Granier, Breslau 